\title{
Identification and Pathogenicity of Lasiodiplodia theobromae and Diplodia seriata, the Causal Agents of Bot Canker Disease of Grapevines in Mexico
}

\author{
J. R. Úrbez-Torres, Department of Plant Pathology, University of California, Davis 95616; G. M. Leavitt, Univer- \\ sity of California Cooperative Extension, Madera 93637; J. C. Guerrero, Departamento de Agricultura, Universidad \\ de Sonora, Hermosillo 83000, Mexico; J. Guevara, Campo Experimental Costa de Ensenada (INIFAP), Baja Cali- \\ fornia 22800, Mexico; and W. D. Gubler, Department of Plant Pathology, University of California, Davis
}

\begin{abstract}
Úrbez-Torres, J. R., Leavitt, G. M., Guerrero, J. C., Guevara, J., and Gubler, W. D. 2008. Identification and pathogenicity of Lasiodiplodia theobromae and Diplodia seriata, the causal agents of bot canker disease of grapevines in Mexico. Plant Dis. 92:519-529.

Perennial cankers and consequent grapevine dieback are a major problem in vineyards of Sonora and Baja California, the most important grape-production areas of Mexico. In order to identify the canker-causing agents, symptomatic arms, cordons, and trunks were collected from 13 and 6 vineyards in Sonora and Baja California, respectively. Two Botryosphaeriaceae spp., Lasiodiplodia theobromae and Diplodia seriata, were isolated frequently from infected wood and identified based on morphological and cultural characters as well as analyses of nucleotide sequences of three genes, the internal transcribed spacer region (ITS1-5.8S-ITS2), a partial sequence of the $\beta$-tubulin gene, and part of the translation elongation factor 1- $\alpha$ gene (EF1- $\alpha)$. Although both $L$. theobromae and $D$. seriata were isolated from grapevine cankers in Baja California, only $L$. theobromae was found in vines in the Sonora region. Pathogenicity of both species was verified by inoculation of rooted cuttings and green shoots of Thompson Seedless and Chardonnay cultivars. Isolates of $L$. theobromae were more virulent, based on the extent of spread in the secondary wood and green tissue, than those of D. seriata. These findings confirm L. theobromae and $D$. seriata as the causal agents of dieback and canker formation of grapevines in northern Mexico.
\end{abstract}

Additional keywords: dead arm, Eutypa dieback, Eutypa lata, trunk diseases, Vitis vinifera

Grapevine (Vitis vinifera L.), cultivated in over 26,000 hectares, is the most important fruit crop in the Mexican States of Baja California and Sonora. These regions are the largest wine and table grapeproducing areas of Mexico and generate an annual crop valued of US\$152 million dollars (39). Grapevine decline in Mexico first was observed in the states of Aguascalientes and Coahuila-Durango in 1979, and was associated with Eutypa lata (Pers.) Tul. \& C. Tul., the causal agent of Eutypa dieback (44). Ten years later, grapevine cankers and subsequent dieback were observed in table-grape vineyards of Hermosillo, Sonora. Disease symptoms were characterized by dead arms and cordons, trunk dieback due to canker formation in the vascular tissue, and the total absence of the stunted chlorotic spring growth which is typical of infections by $E$. lata. Subsequently, these symptoms were associated with Lasiodiplodia theobromae (Pat.) Griffon \& Maubl. (23). For many

Corresponding author: W. D. Gubler

E-mail: wdgubler@ucdavis.edu

Accepted for publication 14 November 2007.

doi:10.1094/PDIS-92-4-0519

(C) 2008 The American Phytopathological Society
D. seriata (=B. obtusa), Neofusicoccum parvum (Pennycook \& Samuels) Crous, Slippers \& A.J.L. Phillips (=B. parva), B. dothidea (Moug.) Ces. \& De Not., D. mutila (Fr.) Mont. (=B. stevensii), N. luteum (Pennycook \& Samuels) Crous, Slippers \& A.J.L. Phillips $(=B$. lutea $)$, and $N$. australe (Slippers, Crous \& M.J. Wingf.) Crous, Slippers \& A.J.L. Phillips (=B. australis) are the most commonly found associated with grapevine dieback worldwide $(2,20,29,43,45,47,48)$.

L. theobromae is a pleomorphic and plurivorous Ascomycete, mostly prevalent in tropical and subtropical climate regions (33). L. theobromae is recognized as an important wood pathogen and has been reported to cause cankers, dieback, and fruit and root rots in over 500 different hosts, including perennial fruit and nut trees, vegetable crops, and ornamental plants (32). Vascular cankers and grapevine dieback caused by L. theobromae first were reported in Egypt in 1972 (13). Fifteen years later, a field study conducted in California showed $L$. theobromae to be an important grapevine pathogen, capable of causing cankers, dieback, and dead arm symptoms on vines (24). The disease has since been referred to as "Bot canker" or "Diplodia cane dieback" and now is known to be prevalent in the warm growing areas of the southern San Joaquin Valley and the Coachella valley in southern California $(17,23,45)$. Recent studies conducted in South Africa and Australia, where L. theobromae was isolated primarily from declining grapevines showing perennial cankers in spurs and cordons, have confirmed the significance of this species as a grapevine pathogen $(43,48,50)$.

$D$. seriata has been observed in temperate areas on most continents and described from over 35 different hosts, including Vitis spp. (34). D. seriata is recognized as an important pathogen of pome and stone fruit trees, causing cankers, leaf spots, and black rot of the fruit $(5,6,22,40,41)$. Unlike L. theobromae, pathogenicity of $D$. seriata in grapevines remains unclear. Whereas studies in Western Australia and Portugal have considered $D$. seriata to be a saprophyte or a weak and secondary pathogen of grapevines, respectively $(28,43)$, other studies report $D$. seriata to be a primary pathogen in grapevines causing vascular 
symptoms such as brown streaking of the wood and cankers in Australia, South Africa, Chile, and France $(2,10,20,37,48)$. Different studies have reported $D$. seriata to be associated with grapevine decline symptoms such as trunk and bark infections in Herzegovina, Yugoslavia (35), xylem necrosis in Italy $(3,36)$, infectious drying of grapes in Ukraine (18), vine decline in Hungary $(16,25)$, perennial cankers in Spain $(1,47)$, "Black dead arm" in Lebanon (11), and darkened pith in New Zealand (4). However, Koch's postulates were not accomplished in most of these studies. Therefore, whether $D$. seriata is acting as a saprophyte or is a pathogen causing grapevine dieback symptoms has not yet been clarified in many grapegrowing regions worldwide.

The purpose of this study was to identify and characterize, by means of morphological features, multigene phylogeny, and pathogenicity studies, the causal agents of grapevine dieback in Mexican vineyards.

\section{MATERIAL AND METHODS}

Field survey, disease symptoms, and fungal isolation. Field surveys were conducted in 2004 in 13 and 6 vineyards in Sonora and Baja California regions, respectively (Fig. 1). Diseased plants were characterized by dead arms and spur positions with poor or no shoot development. Depending on the disease progress, death of the entire part of the cordon or different portions could be observed while other parts of the vine showed normal and healthy growth. Canker development was observed to grow basipetaly from putative points of infection. In all, 55 and 180 cankers were collected from infected arms, cordons, and trunks from different winegrape cultivars (Cabernet Sauvignon, Carignane, Chenin Blanc, Sauvignon

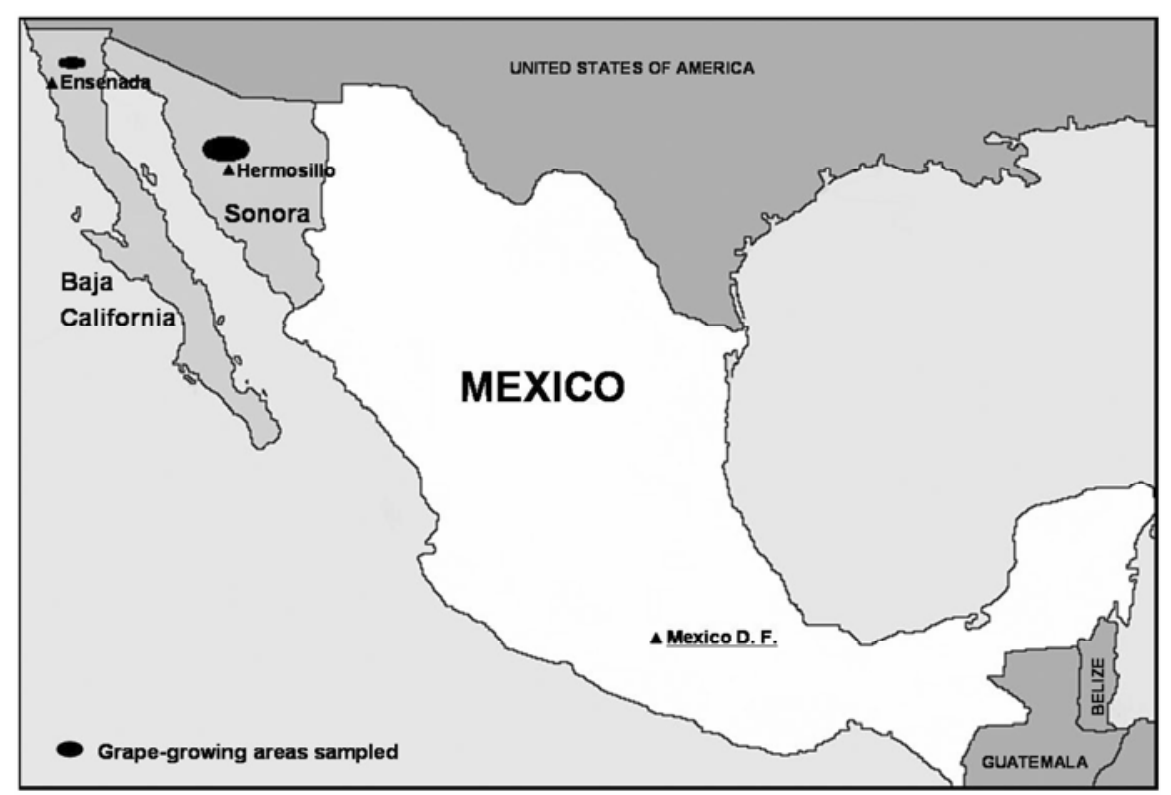

Fig. 1. Map of Mexico indicating the wine-grape region of Baja California and the table-grape region of Sonora where field surveys were conducted.

blanc, and Petit Sirah) in Baja California and from table-grape cultivars (Flame Seedless, Perlette, Sugar One, Rubi Seedless, and Superior) in Sonora, respectively, and brought to the laboratory. Longitudinal and transversal cuts from symptomatic arms, cordons, and trunks were made to observe any internal symptom. Vascular symptoms were characterized by wedgeshaped cankers, which appeared to be associated with pruning wounds (Fig. 2a).

In addition to sectioning, diseased samples were surface sterilized in $10 \%$ sodium hypochlorite for $10 \mathrm{~min}$. Surface tissue was cut away to expose the canker, and wood chips of approximately $1 \mathrm{~cm}^{2}$ were cut from the margin of the dead tissue and cultured on $4 \%$ potato dextrose agar (PDA; Difco, BD Micro Biology Systems, Franklin Lakes, NJ) amended with $0.01 \%$ tetracycline hydrochloride (PDA-tet; SigmaAldrich, St. Louis). Cultures were incubated at $25^{\circ} \mathrm{C}$ until fungal colonies were observed. Botryosphaeriaceae isolates first were separated based on colony morphology by examination of the cultures after 5 , 10 , and 14 days. Fungal mycelium from Botryosphaeriaceae colonies was transferred to fresh PDA-tet petri plates and incubated at room temperature, and hyphal tips from 2-day-old cultures were aseptically placed on PDA petri plates using a dissecting microscope in order to obtain pure cultures. Isolates were incubated at $25^{\circ} \mathrm{C}$ in a 12 -h fluorescent light-and-dark cycle. Based on colony and pycnidia morphology formed in culture of all Botryosphaeriaceae isolates inspected, 20 were selected for detailed identification to species level (Table 1).

Morphological characterization. In all, 15 isolates from both the Baja California and Sonora grapevine regions were used for morphological characterization

520 Plant Disease /Vol. 92 No. 4
(Table 1). Botryosphaeriaceae spp. first were identified based on colony and conidial morphology and by comparing with previous published studies $(29,33,34,43$, 45,47). Colony morphology of Botryosphaeriaceae isolates from Mexico was compared in the laboratory with previously identified Botryosphaeriaceae spp. from California (45) (Table 2). In order to enhance sporulation, cultures were placed on $2 \%$ water agar (Difco, BD Micro Biology Systems) containing autoclaved grapevine wood chips and incubated at $25^{\circ} \mathrm{C}$ under intermittent light $(12 \mathrm{~h})$. Isolates were examined weekly for formation of pycnidia and conidia. Conidial morphology (cell wall, shape, color, and presence or absence of septa) from pycnidia was recorded using a compound microscope (Nikon Inc. Instruments Group, Elville, NY). The length and width of 50 conidia per isolate were measured using the imaging device SPOT RT software (v3.5.1; SPOT; Diagnostic Instruments Inc., MI). Minimum, maximum, mean, standard deviation, and 95\% confidence intervals were calculated from measurements using summary statistics in SAS (SAS System, version 8.1; SAS Institute, Cary, NC). Optimum growth temperature and mycelium growth rates were determined in nine isolates (Table 1) by placing a 4-mmdiameter plug from the growing margin of a 3-day-old colony in the center of an 85mm-diameter PDA petri dish. Three replicates of each isolate were incubated separately in the dark at 5 to $40^{\circ} \mathrm{C}$ at $5^{\circ} \mathrm{C}$ intervals. Colony diameter was measured at $24-$ $\mathrm{h}$ intervals, and data were converted to daily radial growth in millimeters. The experiment was conducted twice. Isolates used in this study are maintained in the collection in the Department of Plant Pathology at the University of California, Davis, and representative isolates of each Botryosphaeriaceae sp. were deposited in the American Type Culture Collection.

DNA extraction, polymerase chain reaction amplification, and multigene phylogenetic analysis. Total genomic DNA from 20 Botryosphaeriaceae isolates (Table 1) was extracted from pure culture mycelia using an AquaPure Genomic DNA Kit (Bio-Rad Laboratories; Hercules, CA). Oligonucleotide primers ITS4 and ITS5 were used to amplify the ITS region of the nuclear ribosomal DNA, including the 5.8S gene (49). Oligonucleotide primers $\mathrm{Bt} 2 \mathrm{a}$ and $\mathrm{Bt} 2 \mathrm{~b}$ were used to amplify a portion of the $\beta$-tubulin (BT) gene (15). Amplification of part of the translation elongation-factor $(\mathrm{EF})$ gene was done with the primers EF1-728F and EF1-986R (8). Each polymerase chain reaction (PCR) contained $5 \mu \mathrm{l}$ of $10 \times$ PCR buffer containing $15 \mathrm{mM} \mathrm{MgCl}_{2}, 2 \mu \mathrm{l}$ of $25 \mathrm{mM} \mathrm{MgCl}$, $1 \mu \mathrm{l}$ of $10 \mathrm{mM} \mathrm{dNTPs}, 2 \mu \mathrm{l}$ of $0.5 \mathrm{mM}$ of each primer, $0.25 \mu \mathrm{l}$ of Taq DNA polymerase (Taq PCR core kit; Qiagen, Valencia, CA) at 5 units $/ \mu$, and $2 \mu$ lof template 
Table 1. Botryosphaeriaceae isolates from Vitis vinifera from Mexico used in this study

\begin{tabular}{|c|c|c|c|c|c|c|c|}
\hline \multirow[b]{2}{*}{ Isolate } & \multirow[b]{2}{*}{ Identity $^{\mathbf{b}}$} & \multirow[b]{2}{*}{ Host ( $V$. vinifera cvs.) } & \multirow[b]{2}{*}{ Origin $^{c}$} & \multicolumn{3}{|c|}{ GenBank accession number ${ }^{\mathrm{a}}$} & \multirow[b]{2}{*}{$\mathbf{A T C C}^{\mathrm{d}}$} \\
\hline & & & & ITS & $\beta$-tubulin & EF1- $\alpha$ & \\
\hline UCD1010BC ${ }^{\mathrm{e}, \mathrm{f}, \mathrm{g}, \mathrm{h}}$ & Diplodia seriata & Cabernet Sauvignon & Ensenada & EU012377 & EU012429 & EU012400 & MYA-4188 \\
\hline $\mathrm{UCD} 1015 \mathrm{BC} \mathrm{e}^{\mathrm{eg}}$ & D. seriata & Carignane & Ensenada & EU012378 & EU012430 & EU012401 & MYA-4189 \\
\hline UCD1035BC & D. seriata & Chenin Blanc & Ensenada & EU012379 & EU012431 & EU012402 & MYA-4190 \\
\hline UCD1038BC ${ }^{\mathrm{e}, \mathrm{f}, \mathrm{g}, \mathrm{h}}$ & D. seriata & Chenin Blanc & Ensenada & EU012380 & EU012432 & EU012403 & MYA-4191 \\
\hline UCD1052BC ${ }^{\mathrm{e}, \mathrm{g}, \mathrm{h}}$ & D. seriata & Sauvignon Blanc & Ensenada & EU012381 & EU012433 & EU012404 & MYA-4192 \\
\hline UCD1061BC $\mathrm{e}, \mathrm{f}, \mathrm{g}$ & D. seriata & Petit Sirah & Ensenada & EU012382 & EU012434 & EU012405 & MYA-4193 \\
\hline UCD1012BCe,g & Lasiodiplodia theobromae & Carignane & Ensenada & EU012372 & EU012424 & EU012392 & MYA-4194 \\
\hline UCD1014BC $\mathrm{e}, \mathrm{f}, \mathrm{g}, \mathrm{h}$ & L. theobromae & Carignane & Ensenada & EU012373 & EU012425 & EU012393 & MYA-4195 \\
\hline $\mathrm{UCD} 1028 \mathrm{BC} \mathrm{e}^{\mathrm{eg}}$ & L. theobromae & Chenin Blanc & Ensenada & EU012374 & EU012426 & EU012394 & MYA-4196 \\
\hline $\mathrm{UCD} 1030 \mathrm{BC} \mathrm{C}^{\mathrm{e}, \mathrm{f}, \mathrm{g}, \mathrm{h}}$ & L. theobromae & Chenin Blanc & Ensenada & EU012375 & EU012427 & EU012395 & MYA-4197 \\
\hline $\mathrm{UCD} 1060 \mathrm{BC} \mathrm{C}^{\mathrm{e}, \mathrm{f}, \mathrm{g}, \mathrm{h}}$ & L. theobromae & Petit Sirah & Ensenada & EU012376 & EU012428 & EU012396 & MYA-4198 \\
\hline $\mathrm{UCD} 10 \mathrm{SN}^{\mathrm{e}, \mathrm{g}}$ & L. theobromae & Flame Seedless & Hermosillo & EU012363 & EU012415 & EU012383 & MYA-4199 \\
\hline UCD881SNg & L. theobromae & Perlette & Hermosillo & EU012364 & EU012416 & EU012384 & MYA-4200 \\
\hline UCD914SNe,f,g,h & L. theobromae & Rubi Seedless & Hermosillo & EU012365 & EU012417 & EU012385 & MYA-4202 \\
\hline UCD916SNg & L. theobromae & Sugar One & Hermosillo & EU012366 & EU012418 & EU012386 & MYA-4203 \\
\hline UCD917SNg & L. theobromae & Sugar One & Hermosillo & EU012367 & EU012419 & EU012387 & MYA-4201 \\
\hline UCD918SNe,f,g,h & L. theobromae & Sugar One & Hermosillo & EU012368 & EU012420 & EU012388 & MYA-4204 \\
\hline UCD919SNe,g,h & L. theobromae & Sugar One & Hermosillo & EU012369 & EU012421 & EU012389 & MYA-4205 \\
\hline UCD921SNg & L. theobromae & Sugar One & Hermosillo & EU012370 & EU012422 & EU012390 & MYA-4206 \\
\hline UCD923SN ${ }^{\mathrm{e}, \mathrm{f}, \mathrm{g}}$ & L. theobromae & Sugar One & Hermosillo & EU012371 & EU012423 & EU012391 & MYA-4207 \\
\hline $\begin{array}{l}\text { a ITS = internal trar } \\
\text { b } \text { Botryosphaeriace } \\
\text { c Isolates from Ens } \\
\text { ted by J. R. Úrbez } \\
\text { d ATCC = America } \\
\text { e Isolates used for c } \\
\text { f Isolates used for t } \\
\text { g Isolates used for } \mathrm{p}\end{array}$ & $\begin{array}{l}\text { Iscribed spacer and EF1- } \alpha= \\
\text { ae spp. from grapevine from } \\
\text { enada, Baja California, Mexi } \\
\text {-Torres, G. Leavitt, and J. C. } \\
\text { n Type Culture Collection. } \\
\text { olony and conidial morpholo } \\
\text { emperature studies. } \\
\text { hylogenetic analyses. }\end{array}$ & $\begin{array}{l}\text { elongation factor. } \\
\text { Mexico were determined } \\
\text { co collected by G. Leavi } \\
\text { Guerrero in February } 20 \\
\text { gy. }\end{array}$ & $\begin{array}{l}\text { based on mor } \\
\text { and J. Gueva }\end{array}$ & $\begin{array}{l}\text { ology and phy } \\
\text { in July } 2004\end{array}$ & $\begin{array}{l}\text { enetic analys } \\
\text { isolates from }\end{array}$ & rmosillo, Son & Mexico collec \\
\hline
\end{tabular}

Table 2. Botryosphaeriaceae isolates used in the phylogenetic study

\begin{tabular}{|c|c|c|c|c|c|c|c|}
\hline \multirow[b]{2}{*}{ Isolate $^{b}$} & \multirow[b]{2}{*}{ Identity } & \multirow[b]{2}{*}{ Host $^{c}$} & \multirow[b]{2}{*}{ Origin } & \multirow[b]{2}{*}{ Collector $^{d}$} & \multicolumn{3}{|c|}{ GenBank accession number ${ }^{a}$} \\
\hline & & & & & ITS & $\beta$-tubulin & EF1- $\alpha$ \\
\hline UCD191Co* & Lasiodiplodia theobromae & $V v$ cv. Flame Seedless & California, USA & J. R. Ú.-T. \& G. L. & DQ008308 & DQ008331 & EU012397 \\
\hline UCD205Co* & L. theobromae & $V v$ cv. Thompson Seedless & California, USA & J. R. Ú.-T. \& G. L. & DQ008310 & DQ008333 & EU012398 \\
\hline UCD206Co* & L. theobromae & $V v$ cv. Perlette & California, USA & J. R. Ú.-T. \& G. L. & DQ008311 & DQ008334 & EU012399 \\
\hline CAA006 & L. theobromae & Vitis vinifera & California, USA & T. J. Michailides & DQ458891 & DQ458859 & DQ458876 \\
\hline CMW9074 & L. theobromae & Pinus sp. & Mexico & B. Slippers & AY236952 & AY236930 & AY236901 \\
\hline CMW10130 & L. theobromae & $V$. donniana & Uganda & J. Roux & AY236951 & AY236929 & AY236900 \\
\hline CBS124.13 & L. theobromae & Unknown & United States & J. J. Taubenhhaus & DQ458890 & DQ458858 & DQ458875 \\
\hline CBS115812 & L.gonubiensis & Syzygium cordatum & South Africa & D. Pavlic & DQ458892 & DQ458860 & DQ458877 \\
\hline UCD244Ma* & Diplodia seriata & $V v$ cv. Thompson Seedless & California, USA & J. R. Ú.-T. \& G. L. & DQ008314 & DQ008337 & EU012406 \\
\hline UCD $352 \mathrm{Mo}^{*}$ & D. seriata & $V v$ cv. Cabernet Sauvignon & California, USA & J. R. Ú.-T. \& G. L. & DQ008315 & DQ008338 & EU012407 \\
\hline UCD614Tu* & D. seriata & $V v$ cv. Muscat & California, USA & J. R. Ú.-T. \& G. L. & DQ008318 & DQ008341 & EU012408 \\
\hline UCD710SJ* & D. seriata & $V v$ cv. Zinfandel & California, USA & J. R. Ú.-T. \& G. L. & DQ008321 & DQ008344 & EU012409 \\
\hline UCD770St* & D. seriata & $V v$ cv. French Colombard & California, USA & J. R. Ú.-T. \& G. L. & DQ008322 & DQ008345 & EU012410 \\
\hline CMW7774 & D. seriata & Ribes sp. & New York, USA & B. S. \& G. H. & AY236953 & AY236931 & AY236902 \\
\hline CMW7775 & D. seriata & Ribes sp. & New York, USA & B. S. \& G. H. & AY236954 & AY236932 & AY236903 \\
\hline CMW8230 & D. seriata & Picea glauca & Canada & J. Reid & AY972104 & AY972119 & DQ280418 \\
\hline CMW8232 & D. seriata & Malus domestica & South Africa & W. A. Smith & AY972105 & AY972120 & DQ280419 \\
\hline CBS119049 & D. seriata & Vitis sp. & Italy & L. Mugnai & DQ458889 & DQ458857 & DQ458874 \\
\hline UCD288Ma & Diplodia mutila & $V v$ cv. Thompson Seedless & California, USA & J. R. Ú.-T. \& G. L. & DQ008313 & DQ008336 & EU012411 \\
\hline UCD1953SB & D. mutila & $V v$ cv. Chenin Blanc & California, USA & J. R. Ú.-T. \& G. L. & DQ233598 & DQ233619 & EU012412 \\
\hline UCD1965SB & D. mutila & $V v$ cv. Chardonnay & California, USA & J. R. Ú.-T. \& G. L. & DQ233599 & DQ233620 & EU012413 \\
\hline CMW7060 & D. mutila & Fraxinus excelsior & The Netherlands & H. A. van der Aa & AY236955 & AY236933 & AY236904 \\
\hline CBS112554 & D. mutila & Pyrus communis & Portugal & A. J. L. Phillips & AY259095 & DQ458851 & DQ458870 \\
\hline CBS230.30 & D. mutila & Phoenix dactylifera & California, USA & L. L. Huillier & DQ458886 & DQ458849 & DQ458869 \\
\hline JL375 & D. mutila & Fraxinus excelsior & Catalonia, Spain & J. Luque & DQ458887 & DQ458852 & DQ458871 \\
\hline CBS 112547 & Diplodia corticola & Quercus ilex & Córdoba, Spain & M. E. Sánchez & AY259110 & DQ458854 & DQ458872 \\
\hline UCD2057Te & Neofusicoccum luteum & $V v$ cv. Cabernet Sauvignon & California, USA & J. R. Ú.-T. \& G. L. & DQ233604 & DQ233625 & EU012414 \\
\hline CBS110299 & N. luteum & $V$. vinifera & Portugal & A.J.L. Phillips & AY928043 & DQ458848 & AY573217 \\
\hline
\end{tabular}

\footnotetext{
a ITS = internal transcribed spacer and EF1- $\alpha=$ elongation factor. cates isolates used for morphological comparison.

c $V v=$ Vitis vinifera.

d J. R. Ú.-T. \& G. L. = J. R. Úrbez-Torres \& G. Leavitt and B. S. \& G. H. = B. Slippers \& G. Hudler.
}

b Acronyms of cultures collections: UCD: University of California, Davis, Plant Pathology Department Culture Collection; CMW: Culture Collection Forestry and Agricultural Biotechnology Institute, University of Pretoria, South Africa; CBS: Centraalbureau Schimmelcultures, Utrecht, Netherlands; * indi- 
DNA adjusted with purified water (Mili-Q Water Systems; Millipore, Billerica, MA) to a final volume of $50 \mu \mathrm{l}$. Amplification reactions were carried out in a thermal cycler (PTC 200; M. J. Research Company, Watertown, MA). ITS and BT temperature profiles were as follows: an initial preheat for $2 \mathrm{~min}$ at $94^{\circ} \mathrm{C}$, followed by 35 cycles of denaturation at $94^{\circ} \mathrm{C}$ for $60 \mathrm{~s}$, annealing at $58^{\circ} \mathrm{C}$ for $60 \mathrm{~s}$, and extension at $72^{\circ} \mathrm{C}$ for $90 \mathrm{~s}$. Translation EF temperature profiles were one cycle of initial denaturation at $95^{\circ} \mathrm{C}$ for $3 \mathrm{~min}$; followed by 35 cycles of denaturation at $95^{\circ} \mathrm{C}$ for $30 \mathrm{~s}$, annealing at $55^{\circ} \mathrm{C}$ for $30 \mathrm{~s}$, and extension at $72^{\circ} \mathrm{C}$ for $60 \mathrm{~s}$; with a final extension at $72^{\circ} \mathrm{C}$ for $5 \mathrm{~min}$. The PCR amplification products were separated by electrophoresis in $1.5 \%$ agarose gels in $1.0 \times$ Tris-boric acid-EDTA (TBE) buffer and photographed under UV light after staining with ethidium bromide for $15 \mathrm{~min}$. PCR products were purified using a QIAquick PCR purification kit (Qiagen). ITS, BT2, and EF1- $\alpha$ regions were sequenced in both directions by the University of California, Davis, Division of Biological Sciences sequencing facility. Sequences were edited and assembled using Sequencher (version 4.1; Gene Codes, Ann Arbor, MI). Sequences were aligned using the computer software BioEdit Sequencer Alignment Editor (version 7.0.0; Tom Hall, Isis Pharmaceuticals, Inc, Carlsbad, CA) and alignment gaps were treated as missing data. Sequences of Botryosphaeriaceae from Mexico were compared with those of Botryosphaeriaceae from previous studies available in GenBank (Table 2). The alignment was corrected by visual inspection, and any ambiguously aligned characters were deleted using BioEdit. A partition

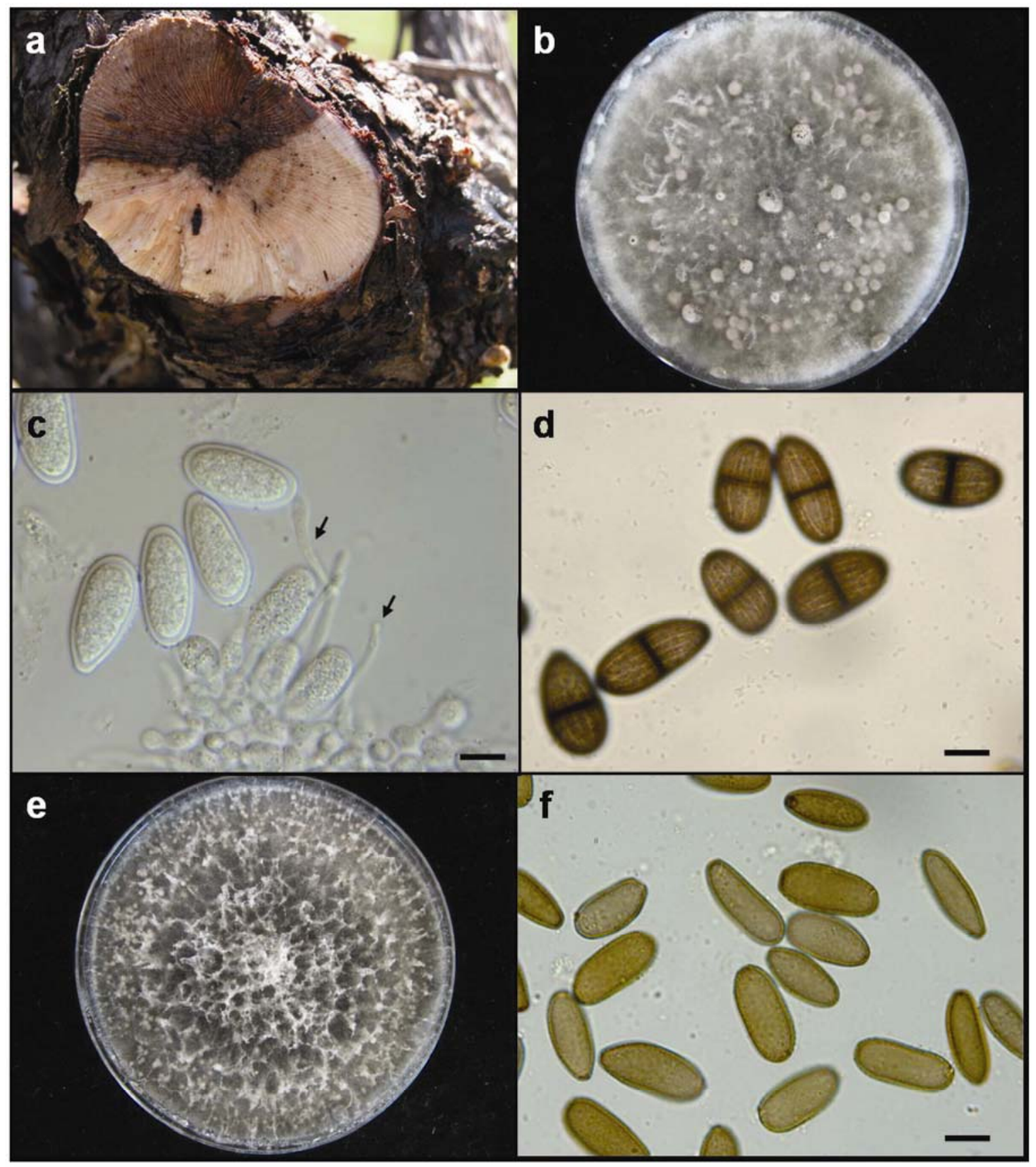

Fig. 2. Disease symptoms and Lasiodiplodia theobromae and Diplodia seriata colony and conidial morphology. a, Cross section of a 14-year-old Thompson Seedless grapevine cordon. Wedge-shaped canker was the primary vascular symptom observed in grapevines in both Baja California and Sonora grapegrowing regions. b, Colony morphology of 21-day-old L. theobromae (UCD919SN). c, Conidiogenous cells and young hyaline and thick-walled L. theobromae (UCD918SN) conidia. Nonseptate paraphyses are indicated by black arrows. d, Dark-brown mature L. theobromae (UCD918SN) conidia. Longitudinal striations and central septum can be observed. e, Colony morphology of 21-day-old D. seriata (UCD1061BC). f, Light-brown mature D. seriata (UCD1061BC) conidia. Conidial photographs were taken at $\times 100$ (immersion oil) from pycnidia formed on grapevine wood. Scale bar $=10 \mu \mathrm{m}$. 
homogeneity test was performed with PAUP (version 4.0b10; Sinauer Associates, Inc., Publishers, Sunderland, MA; 42) to determine whether the ITS, $\beta$-tubulin, and EF1- $\alpha$ datasets could be combined together. Separate phylogenetic analyses also were performed for the ITS dataset alone, $\beta$-tubulin dataset alone, and EF1- $\alpha$ dataset alone, and tree topologies were compared. Maximum parsimony analyses was performed in PAUP using the heuristic search option branch swapping, and 1,000 random addition sequences replicates. Bootstrap values were calculated using 1,000 replicates to test branch strength. Tree length, consistency index (CI), retention index (RI), rescaled consistency index (RC), and homoplasy index (HI) also were recorded. Resulting trees were printed in PAUP version $4.0 \mathrm{~b} 10$. N. luteum sequences from GenBank were used as outgroup (Table 2). The ITS, $\beta$-tubulin, and EF1- $\alpha$ sequences from Botryosphaeriaceae from Mexico used in this study were deposited into GenBank.

Pathogenicity tests. Nine Botryosphaeriaceae isolates were used in two separate tests to determine the pathogenicity of $L$. theobromae and D. seriata from Mexico on grapevines (Table 1). An initial pathogenicity test was conducted in 1-year-old grapevine cuttings of cvs. Chardonnay and Thompson Seedless. In all, 100 dormant cuttings of each cultivar were cut into uniform lengths containing six to seven buds. A basal cut was made just below the lower bud and the upper cut $2 \mathrm{~cm}$ above the top bud. In order to enhance callusing and rooting, dormant cuttings were buried into a 3:1 soil:vermiculite mix in plastic boxes, and placed in a callusing room at $35^{\circ} \mathrm{C}$ and $80 \%$ humidity for 4 weeks at the Viticulture Experimental Station of the University of California, Davis. After callusing and rooting, cuttings were wounded at the uppermost internode with a 4-mm cork borer. A 4-mm mycelium agar plug from a 1 -week-old culture was placed in the wound. Wounds first were covered with $100 \%$ pure Vaseline petroleum jelly (Unilever, Greenwich, CT) and wrapped with parafilm. In all, 10 cuttings per fungal isolate were used for each cultivar. Ten cuttings of each cultivar were inoculated with 4-mm noncolonized PDA agar plugs from two different plates for negative controls. Inoculated cuttings were planted immediately in individual pots and placed in a lathhouse at the University of California Experimental Station in Davis during the last week of April. Plants were arranged in a completely randomized design. Cuttings were maintained under ambient environmental conditions and watered every 3 days or as needed. Cuttings were collected after 20 weeks and inspected for lesion development. Extent of vascular discoloration was measured upward and downward from the point of inoculation. Small pieces $(0.5$ to $1 \mathrm{~cm})$ of necrotic tissue from the edge of each lesion were cut and placed on PDA-tet petri plates in an attempt to recover the inoculated fungus and complete Koch's postulates. Fungal identity was verified by its colony and conidial morphology.

A second pathogenicity test, using the same nine Botryosphaeriaceae isolates from Mexico (Table 1), was conducted on cvs. Chardonnay and Thompson Seedless green shoots. In all, 100 green shoots of approximately $30 \mathrm{~cm}$ in length from each cultivar were cut from vines at the Experimental Station of the University of California, Davis, and immediately inoculated as previously described. Ten green shoots of each cultivar were used per fungal isolate. Ten green shoots of each cultivar were inoculated with 4-mm noncolonized PDA agar plugs from two different plates for negative controls. Green shoots were placed in sterile water into 50-ml screw-cap tubes (Sarstedt, Inc., Newton, $\mathrm{NC)}$ and maintained for 10 days at room temperature on the laboratory bench. Afterward, green shoots were sectioned longitudinally, vascular discoloration was recorded, and green tissue reisolations were made as described above.

One-way analyses of variance (ANOVA) in SAS (SAS System, version 8.1; SAS Institute) was performed in order to assess differences in the extent of vascular discoloration induced by $L$. theobromae and D. seriata for both hardwood and green tissue pathogenicity tests in both cultivars. To satisfy the assumptions of the ANOVA, the $\log _{10}$ transformation of the data was used. Homogeneity of variance was assessed using Levene's test. The Tukey's test was used for comparison of treatment means at $P<$ 0.05. A two-way ANOVA was performed to determine significant differences between cultivars in inoculation of both 1year-old cuttings and green shoots treatments.

Table 3. Morphological description of Lasiodiplodia theobromae and Diplodia seriata isolates from Mexico.

\begin{tabular}{|c|c|c|c|c|}
\hline \multirow[b]{2}{*}{ Identity, isolate } & \multicolumn{2}{|l|}{ Conidial dimensions } & \multicolumn{2}{|c|}{ Temperature study } \\
\hline & Conidial size $(\mu \mathrm{m})^{\mathrm{a}}$ & L/W ratio ra $^{b}$ & Opt. $\left({ }^{\circ} \mathrm{C}\right)^{\mathrm{c}}$ & Growth rated \\
\hline \multicolumn{5}{|l|}{ D. seriata ${ }^{\mathrm{e}}$} \\
\hline UCD1010BC & $(29.2-) 23.6-16.8(-12.6) \times(12.8) 10.7-8.4(-7.4)$ & 2.1 & $25-30$ & 17.5 \\
\hline UCD1015BC & $(26.7-) 22.6-17.6(-14.5) \times(12) 11.4-8.4(-7.9)$ & 2.03 & & \\
\hline UCD1038BC & $(26.6-) 23.6-18(-13.2) \times(12.7) 11.1-8.7(-7.2)$ & 2.1 & $25-30$ & 26.3 \\
\hline UCD1052BC & $(24.2-) 22.1-18.5(-16.7) \times(12.9) 10.6-8.3(-7.1)$ & 2.13 & $\ldots$ & 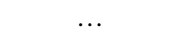 \\
\hline UCD1061BC & $(28.7-) 22.7-17.1(-13.1) \times(11) 10.1-8.3(-7.1)$ & 2.16 & $25-30$ & 19.8 \\
\hline \multicolumn{5}{|l|}{ L. theobromae f } \\
\hline UCD1012BC & $(28.5-) 26.7-22.5(-19.9) \times(17.8) 14.6-12.4(-11.5)$ & 1.8 & & \\
\hline UCD1014BC & $(37.3-) 28.7-22.1(-14.9) \times(16.3) 13.9-11.9(-10)$ & 1.9 & $30-35$ & 42.5 \\
\hline UCD1028BC & $(28.3-) 26.2-22.6(-19.7) \times(16.4) 14.7-12.3(-11.4)$ & 1.8 & $\ldots$ & $\ldots$ \\
\hline UCD1030BC & $(31.6-) 26.8-22.2(-17.7) \times(16.6) 14.5-12.3(-11.2)$ & 1.8 & $30-35$ & 37.2 \\
\hline UCD1060BC & $(29.3-) 27.2-23.4(-21.7) \times(15.7) 14.1-12.3(-11.1)$ & 1.9 & 35 & 42.5 \\
\hline UCD810SN & $(30.1-) 27.8-23(-20.5) \times(14.9) 13.8-11.8(-10)$ & 2 & & $\ldots$ \\
\hline UCD914SN & $(30.9-) 27.6-22.8(-19.8) \times(15.2) 13.8-11.2(-9.8)$ & 2 & 35 & 36.9 \\
\hline UCD918SN & $(29.1-) 27.4-24(-21.8) \times(14.9) 13.9-11.7(-10.8)$ & 2 & $30-35$ & 42.5 \\
\hline UCD919SN & $(34.5-) 28.3-23.1(-20.1) \times(16.7) 13.5-10.7(-9.1)$ & 2.1 & 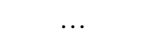 & $\ldots$ \\
\hline UCD923SN & (34.4-) $28.8-23.6(-21.4) \times(15) 13.1-10.5(-9.3)$ & 2.2 & 35 & 42.5 \\
\hline
\end{tabular}

\footnotetext{
a Data are represented as the lower and upper $95 \%$ confidence limits, with maximum and minimum dimensions in parenthesis.

${ }^{\mathrm{b}} \mathrm{L} / \mathrm{W}=$ length/width.

${ }^{\mathrm{c}}$ Optimum temperature is defined as the temperature that produced maximum radial growth after $48 \mathrm{~h}$.

d Maximum mycelium radial growth in millimeters after $48 \mathrm{~h}$.

e Colony morphology: Moderate aerial mycelium. Light-green colonies that became dark green with age. Colonies produced many black, single, small (0.5-1 $\mathrm{mm}$ in diameter), and ostiolate pycnidia. Conidial morphology: Elliptical-rounded with one of the bases truncated. Immature conidia initially hyaline and thick-walled. Light brown to dark brown when mature. Aseptate conidia.

${ }^{f}$ Colony morphology: Abundant aerial mycelium. White colonies with a light-green center. Entire colony became dark-green with age. Colonies produced black, grouped, large (up to $7 \mathrm{~mm}$ diameter), ostiolate, and globose pycnidia, embedded in stroma. Conidial morphology: Oval with rounded and pointed ends. Immature conidia hyaline, thick-walled, aseptate and densely granulated. Aseptate paraphyses. Conidia dark brown with longitudinal striations and one septum when mature.
} 


\section{RESULTS}

Field survey. Botryosphaeriaceae spp. were the most common fungi isolated from grapevine perennial cankers in both Baja California and Sonora grape-growing regions. D. seriata was found in all vineyards surveyed in Baja California and was isolated from 21 of 55 perennial cankers (38\%). L. theobromae was found in four of six vineyards in Baja California and was isolated from 9 of 55 grapevine cankers (16\%). In this study, D. seriata and $L$. theobromae were not isolated together from the same canker in any of the samples from Baja California. Other sporadically isolated fungi from cankers in Baja California (5\%) were species of Alternaria and Aspergillus. L. theobromae was the only fungus isolated from grapevine cankers in Sonora region. L. theobromae was found in all vineyards sampled in Sonora and was isolated from 140 of 180 grapevine cankers $(80.5 \%)$.

Morphological characterization. Isolates of Botryosphaeriaceae from Baja California and Sonora were separated into two groups based on their appearance in culture, conidial morphology and size, and optimum growth temperature (Table 3; Fig. 2). Based on the morphological characters observed and by comparing them with those previously reported $(2,20,29$, $33,34,43,45,47)$, isolates from Mexico were identified as L. theobromae (Fig. 2bd) and D. seriata (Fig. 2e and f).

Phylogenetic analysis. ITS, $\beta$-tubulin, and EF1- $\alpha$ sequences of $L$. theobromae and $D$. seriata from grapevines from Mexico (Table 1) were aligned with GenBank ITS, $\beta$-tubulin, and EF1- $\alpha$ sequences of Botryosphaeriaceae spp. from grapevines and other hosts from different countries (Table 2). After alignment, a partition homogeneity test showed a value of $P=0.09$, indicating that the ITS, $\beta$-tubulin, and EF1- $\alpha$ datasets were congruent $(P>0.05)$ and could be combined in a single phylogenetic analysis. The combined dataset consisted of 1,246 characters, of which 954 were constant, 52 were parsimony uninformative, and 240 were parsimony informative. The maximum parsimony analyses yielded one most parsimonious tree (length $=477, \mathrm{CI}=0.786, \mathrm{RI}=0.955$, $\mathrm{RC}=0.751$, and $\mathrm{HI}=0.214$; Fig. 3 ). The combined data set phylogenetic tree included two well-separated clades. L. theobromae isolates formed a strongly supported clade, with bootstrap value of $100 \%$ (Fig. 3). L. theobromae isolates from Mexico had nearly identical sequences and were grouped together with $L$. theobromae isolates from California (Fig. 3). D. seriata isolates from Mexico resided in a wellsupported separate clade with bootstrap value of $100 \%$ (Fig. 3). D. seriata isolates from Mexico grouped together with $D$. seriata isolates from California, New York, Canada, South Africa, and Italy, showing almost no variation in the DNA sequences
(Fig. 3). Analyses of the ITS, $\beta$-tubulin, and EF1- $\alpha$ datasets alone yielded the same tree topology as the combined dataset (trees not shown), and the only differences between trees generated from different datasets were changes in the positions of some isolates within one of the main clades. Results from both the combined and single datasets of the ITS, $\beta$-tubulin, and EF1- $\alpha$ DNA sequences verified the morphological identifications of $L$. theobromae and $D$. seriata from grapevines from Mexico.

Pathogenicity tests. Mean lengths of the extent of vascular discolorations caused by $L$. theobromae and $D$. seriata isolates from Mexico on inoculated 1-yearold cuttings and green shoots are shown in Figure 4. L. theobromae and D. seriata produced dark-brown, black necrotic lesions on both 1-year-old cuttings and green shoots, which extended upward and downward from the point of inoculation (Fig. 5b, e, and f). Dark wood streaking or discoloration also was observed in green shoots and 1-year-old cuttings of both cultivars inoculated with $L$. theobromae (UCD914SN, UCD921SN, and UCD 1014BC) and D. seriata (UCD1015BC, UCD1038BC, and UCD1061BC) (Fig. $5 \mathrm{eI})$. Differences in susceptibility between L. theobromae and D. seriata in 1-year-old Chardonnay cuttings were evident. Chardonnay cuttings inoculated with $L$. theobromae isolates rarely developed spring growth and, when developed, young shoots, petioles, and leaves died back and dried out very rapidly. Chardonnay cuttings inoculated with $D$. seriata isolates developed healthy spring growth which did not differ from the control (Fig. 5a). Wedge-shaped cankers and necrotic tissue produced by both species were observed when cross sections were made in 1-yearold cuttings and green shoots, respectively (Fig. 5c, d, g, and h). Pycnidia were observed on both wood and green shoot surfaces in plants inoculated only with all $L$. theobromae isolates but not with the $D$. seriata isolates (Fig. 5i).

$L$. theobromae and D. seriata isolates used in this study were pathogenic and caused longer basipetal than acropetal lesions in all treatments (Fig. 4). L. theobromae isolates from Mexico were more virulent and produced significantly longer basipetal lesions in all inoculated plants than those of D. seriata (Figs. 4 and Fig. $5 \mathrm{a}$ and f). D. seriata isolates produced substantially smaller lesions than those caused by L. theobromae in all inoculated 1 -year-old cuttings and green shoots but still differed significantly in symptom expression from control treatments (Fig. 4). However, two D. seriata isolates (UCD1010BC and UCD1038BC) did not cause lesions in 1-year-old Chardonnay cuttings (Fig. 4A). L. theobromae caused significantly $(F=40.89, \mathrm{DF}=9, P<$ 0.0001 ) longer lesions (range from 301.1 to $338.3 \mathrm{~mm}$ ) in 1-year-old Chardonnay cuttings than those in Thompson Seedless (range from 71.2 to $183.1 \mathrm{~mm}$ ) (Fig. 4A and B). Lesions caused by L. theobromae in Thompson Seedless green shoots ranged from 58.6 to $85.4 \mathrm{~mm}$ and differed significantly $(F=5.1, \mathrm{DF}=9, P=0.0254)$ from the lesions caused in Chardonnay (range from 20.9 to $45.5 \mathrm{~mm}$ ) (Fig. 4C and D). D. seriata isolates from Mexico showed no significant differences $(F=0.35, \mathrm{DF}=9, P$ $=0.555)$ in the extent of vascular discoloration between cultivars in both 1-yearold cuttings and green shoots (Fig. 4A-D). Lesions caused by $D$. seriata in 1-year-old Chardonnay and Thompson Seedless cuttings varied from 21.8 to 50.9 and 36.8 to $49.6 \mathrm{~mm}$, respectively. D. seriata caused lesions on green Chardonnay and Thompson Seedless shoots that ranged from 4.2 to 6.2 and 3.7 to $8.7 \mathrm{~mm}$, respectively. $L$. theobromae was reisolated from infected tissue in both 1-year-old cuttings and green shoots in $100 \%$ of the samples. D. seriata was reisolated in $100 \%$ of the samples from 1-year-old cuttings and between 80 to $90 \%$ from green shoots. No Botryosphaeriaceae fungi were reisolated from the control treatments.

\section{DISCUSSION}

Botryosphaeriaceae spp. recently have been shown to be a more prevalent and important wood pathogen on grapevines than originally thought. In total, 14 different Botryosphaeriaceae spp. have been described associated with grapevine dieback from the most important grapegrowing areas of North and South America $(2,14,21,24,27,38,45,46)$, Europe $(1,20,25$, 26,29,47), Africa (13,48), Asia (19), and Oceania $(4,10,37,43,50)$. The present study has shown that two Botryosphaeriaceae spp., L. theobromae and D. seriata, also are associated with grapevine cankers in Mexico.

Perennial cankers and grapevine dieback have been known to occur in Mexico since the late 1970s, when Eutypa dieback was associated with grapevine decline in old and abandoned vineyards in the grapegrowing areas of Coauhila-Durango and Aguascalientes (44). However, this association was based mainly on the discovery of E. lata perithecia in old pruning wounds, and no confirmation of the fungus isolated from declining vines and cankers was reported. Therefore, future field surveys and canker isolations from those grapevine areas may reveal the presence of other fungal pathogens (in addition to $E$. lata), such as species of Botryosphaeriaceae associated with the dieback symptoms reported in the past. Because Eutypa dieback of grapevines has been known and well studied for more than 30 years and because cankers caused by both E. lata and Botryosphaeriaceae spp. are indistinguishable, E. lata has been considered as the primary canker causing agent of grapes 
worldwide. Our surveys in Sonora and Baja California have shown cankers, dead spurs with lack of spring growth, and dead cordons as the primary symptoms on declining vines. Characteristic Eutypa dieback symptoms such as stunted shoots, shortened internodes, and chlorotic and abnormal growth of the leaves were not observed during our sample collections in either the Sonora or Baja California regions. Furthermore, L. theobromae and $D$. seriata were the main fungi isolated from canker lesions in the current study whereas $E$. lata was not recovered from any of the cankers collected. Cankers produced by $E$. lata are rarely observed in vineyards younger than 10 years old due to the slow movement of the fungus through the vascular system following infection of a pruning wound (9). In the current study, we isolated $L$. theobromae from cankers collected from vineyards 5 to 7 years old in the Sonora region. This result agrees with a previous study conducted by Leavitt, in which L. theobromae commonly was isolated from cankers on 5-year-old grapevines in Southern California (23). These results suggest that $L$. theobromae is a faster wood colonizer than E. lata.

The dominance of Botryosphaeriaceae spp. and the absence of E. lata from grapevines in Baja California and Sonora may be due to climatic conditions. E. lata perithecia commonly are found in old vines from grape regions with an annual precipitation over $600 \mathrm{~mm}$ but rarely are found in areas with precipitation lower than $300 \mathrm{~mm}$ per year (9). Weather data recorded during the last 50 years show much lower annual precipitation in both the Ensenada $(283 \mathrm{~mm})$ and Hermosillo $(240 \mathrm{~mm})$ surveyed grapevine areas than in Aguascalientes $(537 \mathrm{~mm})$, from which $E$. lata perithecia mainly were reported to occur in Mexico. Similarly, field surveys conducted throughout the warm and desert areas of Southern California and Western and Eastern Australia have reported isola-

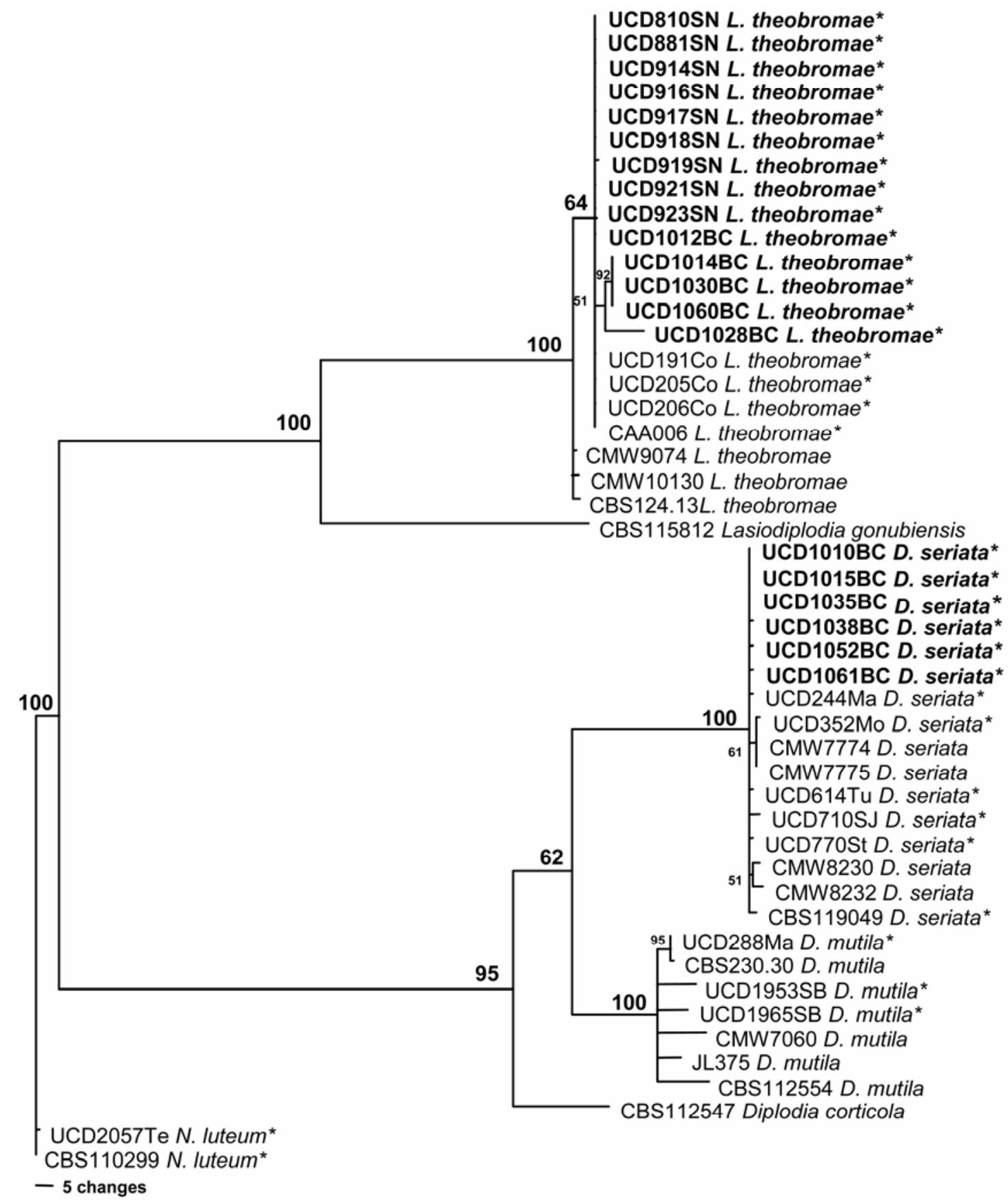

Fig. 3. Most equally parsimonious tree with bootstrap values obtained from the combined internal transcribed spacer, $\beta$-tubulin, and elongation factor- 1 sequence data using 1,000 replicates generated in PAUP 4.0b10. Asterisks show Botryosphaeriaceae spp. from Vitis vinifera. Isolates from Mexico are indicated in bold. 
tion of Botryosphaeriaceae spp. but no $E$. lata from cankers and necrotic lesions $(10,23,37,43,45)$. However, other environmental factors, the lack of many of the susceptible hosts to E. lata in desert areas, as well as the possibility that E. lata has not been yet introduced in Baja California and Sonora also could explain the dominance of Botryosphaeriaceae spp. in these regions.

Morphological characteristics combined with analyses of DNA sequences allowed us to identify and characterize L. theobromae and D. seriata from grapevine cankers from Mexico. Colony and conidial morphology were the most helpful features with which to identify and distinguish $L$. theobromae from $D$. seriata. L. theobromae isolates used in this study grew much faster than those of $D$. seriata and were able to fully colonize an 85-mm-diameter petri plate in $48 \mathrm{~h}$. Furthermore, isolates of L. theobromae showed a higher optimum growth temperature than those of $D$. seriata. These results are in agreement with a previous temperature study conducted with Botryosphaeriaceae isolates from California, in which $L$. theobromae and $D$. seriata isolates achieved maximum growth rates at 31 and $26^{\circ} \mathrm{C}$, respectively (45). Conidial shape and color and the presence of septa and longitudinal striations were robust characteristics for identification and separation of $L$. theobromae from $D$. seriata.
The utility of these morphological distinctions is in agreement with previous literature $(23,32,43,45,50)$. Another important morphological characteristic for the identification of $L$. theobromae was the presence of aseptate paraphyses observed in immature pycnidia. This feature was reported in a recent study, in which aseptate paraphyses along with conidial size were the primary morphological characteristics to separate L. theobromae from other Lasiodiplodia spp. found in the tropics (7).

DNA sequence comparisons allowed us to verify the morphological identification of $L$. theobromae and $D$. seriata from grapevines in Mexico. Results of the single as well as the combined ITS, $\beta$-tubulin, and EF1- $\alpha$ phylogenetic analyses clearly separated $L$. theobromae isolates from $D$. seriata isolates. The remaining Botryosphaeriaceae isolates with Diplodia-like anamorphs that were included in the analyses, such as D. mutila and D. corticola, clustered together within the $D$. seriata clade. In our study, L. theobromae from Mexico grouped together with $L$. theobromae isolates from the desert area known as the Coachella Valley in California, reinforcing the idea that this fungus is prevalent in regions with high temperatures $(17,23,32,45)$. Furthermore, the similarity between $L$. theobromae sequences from grapevines in Mexico and California could support the hypothesis that this species was introduced accidentally in Mexico from California or vice versa. However, more intensive sampling and, perhaps, also more sensitive measures of interisolate relationships, such as microsatellites or vegetative compatibility studies, would be required to test this hypothesis. L. theobromae isolates from Mexico and California differed from isolates CMW9074 and CMW10130 from South Africa and isolate CBS124.13 from an unknown origin in the United States. Host and geographical differences could explain the variation in the DNA sequences between these isolates. In contrast, D. seriata isolates from Mexico grouped together with $D$. seriata isolates from other geographical regions and different hosts showing almost no variation in the DNA sequences. This result agrees with previous phylogenetic studies conducted with $D$. seriata isolates from California (45) and may explain the cosmopolitan distribution of $D$. seriata worldwide.

Pathogenicity tests conducted in 1-yearold cuttings and green shoots of cvs. Chardonnay and Thompson Seedless confirmed that $L$. theobromae and D. seriata isolates from Mexico were pathogenic. In these tests, $L$. theobromae isolates produced much larger lesions than those of $D$. seriata in all inoculated 1-year-old cuttings and green shoots. These results are consistent with previous pathogenicity trials

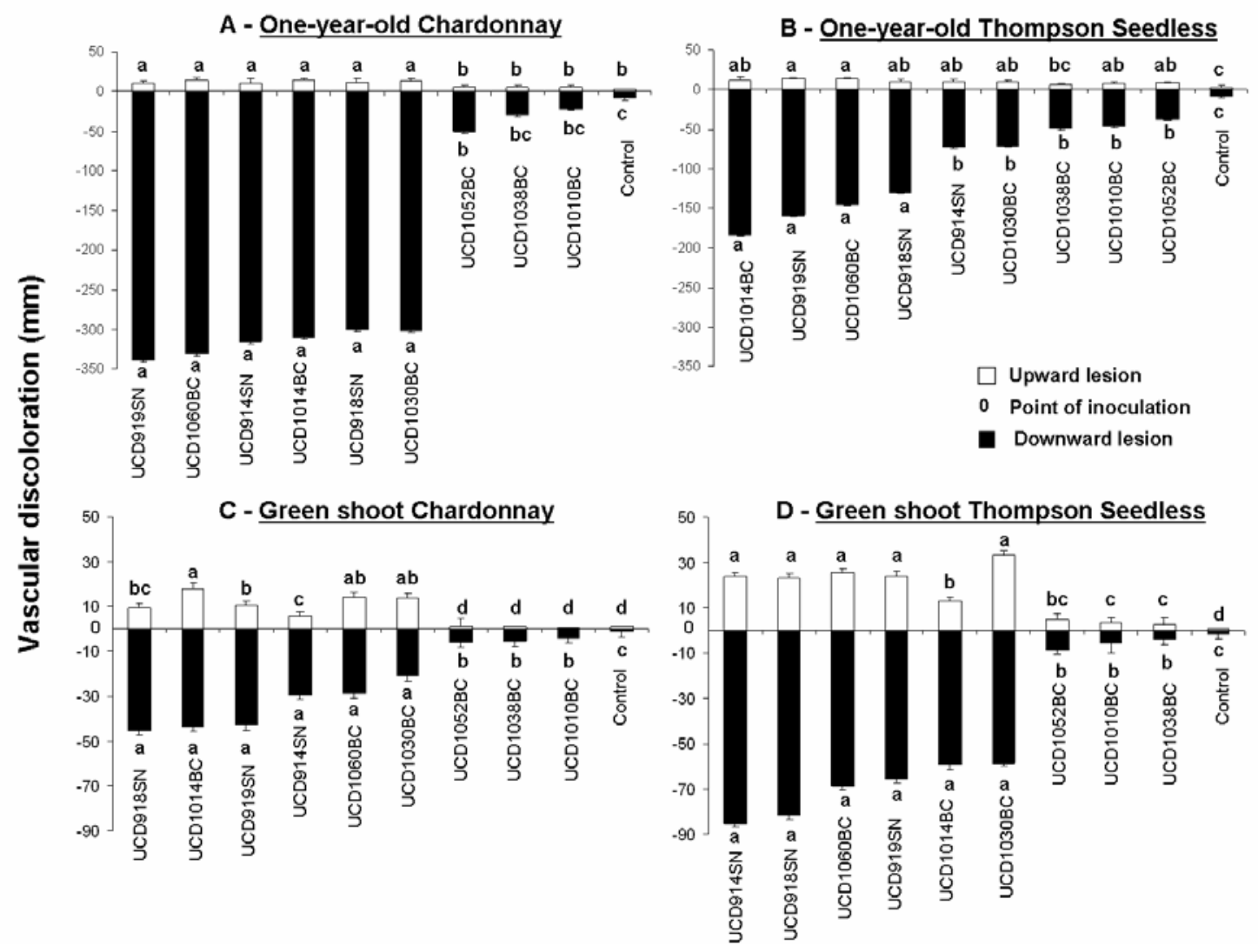

Fig. 4. Pathogenicity study of Lasiodiplodia theobromae and Diplodia seriata in 1-year-old cuttings and green shoots of cvs. Chardonnay and Thompson Seedless. Mean lesion length is based on 10 replicates per isolate. Means followed by different letters differ significantly $(P<0.05)$ according to Tukey's test. Bars represent standard error of the mean. 

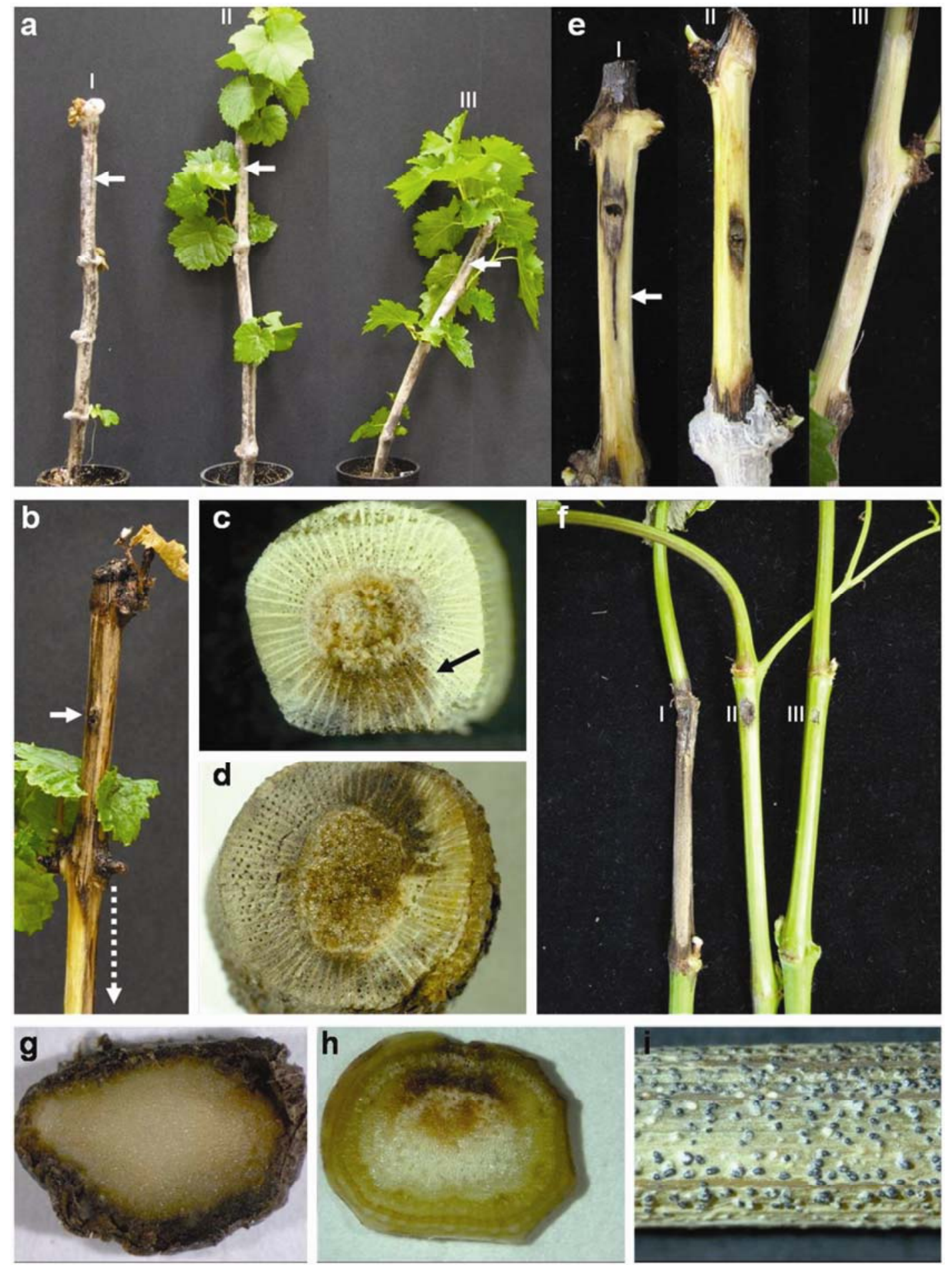

Fig. 5. Pathogenicity of Lasiodiplodia theobromae and Diplodia seriata on a, 1-year-old Chardonnay cuttings 8 weeks after inoculation (aI $=$ L. theobromae UCD914SN, aII = D. seriata UCD1052BC, and aIII = control). White arrows show the point of inoculation. b, Vascular lesion caused by $L$. theobromae (UCD1060BC) in 1-year-old Chardonnay cutting 8 weeks after inoculation. Dark-brown lesion can be observed upward and downward from the point of inoculation causing the death of the wood and leaf dieback at the last internode. Canker continues growing basipetaly throughout the second internode as shown by the dashed white arrow. c, Cross-section in 1-year-old Chardonnay cutting showing a young wedge-shaped canker caused by D. seriata (UCD1052BC) 20 weeks after inoculations. Black arrow shows the edge of the canker. d, Cross-section in 1-year-old Chardonnay cutting showing the canker caused by L. theobromae (UCD919SN) 20 weeks after inoculations. Light-gray area shows dead wood caused by the total vascular colonization of the fungus. Dark-brown area shows the fungus still growing and colonizing healthy vascular tissue. e, Lesions caused in 1-year-old Thompson Seedless cuttings 20 weeks after inoculation $(\mathrm{eI}=L$. theobromae $\mathrm{UCD} 914 \mathrm{SN}$, eII $=$ D. seriata $\mathrm{UCD} 1052 \mathrm{BC}$, and $\mathrm{eII}=$ control). White arrow shows black wood streaking caused by $L$. theobromae moving downward the point of inoculation. No lesions were observed on the noncolonized inoculated controls. f, Lesions caused on Thompson Seedless green shoots 10 days after inoculation ( $\mathrm{fI}=$ L. theobromae UCD918SN, fII $=$ D. seriata UCD1038BC, and fIII $=$ control). $\mathbf{g}$, Crosssection in a Thompson Seedless green shoot showing the necrotic tissue caused by L. theobromae (UCD1060BC) 10 days after inoculation. $\mathbf{h}$, Cross-section in a Thompson Seedless green shoot showing a smaller necrotic lesion caused by D. seriata (UCD1052BC) 10 days after inoculation. i, Pycnidia of $L$. theobromae (UCD914SN) formed on Chardonnay green shoot surface 10 days after inoculation. 
conducted in California and South Africa, in which $L$. theobromae was shown to be one of the most virulent species tested on mature grapevine canes $(23,48)$. However, differences in isolates of $L$. theobromae also have been reported from a recent study conducted in Western Australia, where only one of seven $L$. theobromae isolates produced lesions significantly different from the noninoculated controls (43).

In the current study, 1-year-old Chardonnay cuttings were more susceptible to infection by L. theobromae than Thompson Seedless. The table-grape cv. Thompson Seedless is recommended in grape regions with more than 4,000 degree-days per year. Consequently, Thompson Seedless has long been planted in the warm and desert grape-growing areas of Southern California and Northern Mexico where L. theobromae commonly is found. Similar results were obtained in a pathogenicity study in Western Australia, in which $L$. theobromae isolates were avirulent or only weakly pathogenic in inoculated Red Globe mature canes (43). Red Globe is another table-grape cultivar widely planted in warm regions with more than 4,000 degree-days per year. Thompson Seedless green shoots were more susceptible to infection by $L$. theobromae than were Chardonnay shoots. The reason for this difference in susceptibility is still unknown. Furthermore, the lack of multicultivar Botryosphaeriaceae pathogenicity tests limits comparison of our results to those of previous studies. More field inoculations of diverse cultivars are needed to better characterize the range of susceptibilities.

D. seriata isolates from Mexico were much less pathogenic than those of $L$. theobromae but still capable of causing larger lesions than were evident in the noninoculated controls. This result agrees with previous pathogenicity studies conducted in South Africa, the New South Wales region in Australia, Eastern Australia, Chile, and France, in which D. seriata has been reported to be pathogenic in grapevines $(2,10,20,37,48)$. In contrast, $D$. seriata isolates from grapevines in Western Australia were found to be nonpathogenic (43). We found D. seriata isolates from Mexico to be more pathogenic on 1-yearold cuttings than on green shoots. Differences in pathogenicity and virulence also have been reported among $D$. seriata isolates in South Africa, Eastern Australia, and France $(20,37,48)$. Furthermore, in France, Chile, and Lebanon, D. seriata has been associated with a disease called "Black dead arm" characterized by lightbrown wood streaking and red patches at the margin of leaves, with large areas of chlorosis and deterioration between the veins $(2,11,20)$. The symptoms observed in Baja California and Sonora were not those associated with Black dead arm. This agrees with previous studies conducted in California and Portugal $(28,45)$, which found that there were no foliar symptoms associated with this pathogen. Variable reports on the pathogenicity of $D$. seriata from different grape-growing regions throughout the world may reflect differences in (i) virulence of the isolate used, (ii) cultivar susceptibilities, (iii) inoculation methods, or (iv) incubation times, among other possibilities. Results from this study have confirmed $L$. theobromae and $D$. seriata as the primary causal agents of Bot canker of grapevines in Mexico, indicating the important role that these fungi can play in grapevine health, in general.

\section{ACKNOWLEDGMENTS}

We thank T. Michailides (Department of Plant Pathology, University of California, Kearney Agricultural Center) and T. Gordon (Department of Plant Pathology, University of California, Davis) for providing valuable advice on the writing of this manuscript; and M. Davis (Department of Plant Pathology, University of California, Davis) for his assistance in the phylogenetic analyses.

\section{LITERATURE CITED}

1. Armengol, J., Vicent, A., Torné, L., GarcíaFigueres, F., and García-Jiménez, J. 2001. Fungi associated with esca and grapevine decline in Spain: A three-year survey. Phytopathol. Mediterr. 40:325-329.

2. Auger, J., Esterio, M., Ricke, G., and Pérez, I. 2004. Black dead arm and basal canker of Vitis vinifera cv. Red Globe caused by Botryosphaeria obtusa in Chile. Plant Dis. 88:1286.

3. Bisiach, M., and Minervini, G. 1985. Libertella blepharis A. L. Smith e altri funghi associate a una sindrome atipici nella vite. Vignevini 12:31-35.

4. Bonfiglioli, R., and McGregor, S. 2006. The Botryosphaeria conundrum; a New Zealand perspective. Aust. N. Z. Grapegrow. Winemaker. September:49-53.

5. Britton, K. O., and Hendrix, F. F., 1989. Infection of peach buds by Botryosphaeria obtusa. Plant Dis. 73:65-68.

6. Brown, E. A., and Britton, K. O. 1986. Botryosphaeria diseases of apple and peach in the Southeastern United States. Plant Dis. 71:375379.

7. Burgess, T. I., Barber, P. A., Mohali, S., Pegg, G., de Beer, W., and Wingfield, M. J. 2006. Three new Lasiodiplodia spp. from the tropics, recognized based on DNA sequence comparisons and morphology. Mycologia 98:423-435.

8. Carbone, I., Anderson, J. B., and Kohn, L. M. 1999. A method for designing primer sets for the speciation studies in filamentous ascomycetes. Mycologia 91:553-556.

9. Carter, M. V. 1996. Eutypa dieback. Pages 3234 in: Compendium of Grape Diseases. American Phytopathological Society Press, St. Paul, MN.

10. Castillo-Pando, M., Somers, A., Green, C. D., Priest, M., and Sriskanthades, M. 2001. Fungi associated with dieback of Semillon grapevines in the Hunter Valley of New South Wales. Aust. Plant Pathol. 30:59-63.

11. Choueiri, E., Jreijiri, F., Chlela, P., Louvet, G., and Lecomte, P. 2006. Occurrence of grapevine decline and first report of Black dead arm associated with Botryosphaeria obtusa in Lebanon. Plant Dis. 90:115.

12. Crous, P. W., Slippers, B., Wingfield, M. J., Rheeder, J., Marasas, W. F. O., Phillips, A. J. L., Alves, A., Burgess, T., Barber, P., and Groenewald, J. Z. 2006. Phylogenetic lineages in the Botryosphaeriaceae. Stud. Mycol. 55:235253.

13. El-Goorani, M. A., and El Meleigi, M. A. 1972. Dieback of grapevine by Botryodiplodia theobromae Pat. in Egypt. Phytophatol. Mediterr. 11:210-211.

14. Filho, O. P., Ribeiro, I. J. A., and Kuniyuki, H. 1995. Podridao do tronco da videira (Vitis vinifera) causada por Dothiorella sp., forma anamorfica da Botryosphaeria dothidea. Summa Phytopathol. 21:40-42.

15. Glass Louise, N., and Donaldson, G. C. 1995. Development of primer sets designed for use with the PCR to amplify conserved genes from filamentous Ascomycetes. Appl. Environ. Microbiol. 61:1323-1330.

16. Horváth, A., and Schweighardt, L. 1991. The cause of vine stock decline and experiences of grape rejuvenation in Neszmély. (Abstr.) Rev. Plant Pathol. 71:435.

17. Hewitt, R. W. B. 1996. Diplodia cane dieback and bunch rot. Pages 25-26 in: Compendium of Grape Diseases. American Phytopathological Society Press, St. Paul, MN.

18. Kozar, I. M., Berezovskaya, E. A., Khorunzahaya, G. M., and Klimenko, L. N. 1990. Control of the causal agents of infectious drying of grapes in Ukraine. (Abstr.) Rev. Plant Pathol. 71:598.

19. Kuo, K.C., Kao, C. W., and Leu, L. S. 1989. Grape cluster rot caused by Botryosphaeria ribis. Plant Prot. Bull. Taiwan 31:238-247.

20. Larignon, P., Fulchic, R., Cere, L., and Dubos, B. 2001. Observations of Black dead arm in French vineyards. Phytophathol. Mediterr. 40:336-342.

21. Latorre, B. A., Besoaín, X., and Flores, V. 1986. Botryosphaeria canker of table grapes. (Abstr.) Phytopathology 76:1112.

22. Latorre, B. A., and Toledo, M. V. 1984. Occurrence and relative susceptibility of apple cultivars to Botryosphaeria canker in Chile. Plant Dis. 68:36-39.

23. Leavitt, G. M. 1990. The occurrence, distribution, effects and control of Botryodipodia theobromae on Vitis vinifera in California, Arizona and northern Mexico. Ph.D. dissertation, University of California, Riverside.

24. Leavitt, G. M., and Munnecke, D. E. 1987. The occurrence, distribution, and control of Botryodiplodia theobromae on grapes (Vitis vinifera) in California. (Abstr.) Phytopathology 77:1690.

25. Lehoczky, J. 1974. Black dead arm disease of grapevine caused by Botryosphaeria stevensii infection. Acta Phytopathol. Hung. 9:319-327.

26. Luque, J., Martos, S., and Phillips, A. J. L. 2005. Botryosphaeria viticola sp. nov. on grapevines: a new species with a Dothiorella anamorph. Mycologia 97:1111-1121.

27. Milholland, R. D. 1988. Macrophoma rot. In: Compendium of Grape Diseases. American Phytopathological Society Press, St. Paul, MN.

28. Phillips, A. J. L. 1998. Botryosphaeria dothidea and other fungi associated with excoriose and dieback of grapevines in Portugal. J. Phytophatol. 146:327-332.

29. Phillips, A. J. L. 2002. Botryosphaeria species associated with diseases of grapevines in Portugal. Phytopathol. Mediterr. 41:3-18.

30. Phillips, A. J. L., Alves, A., Correia, A., and Luque, J. 2005. Two new species of Botryosphaeria with brown, 1-septate ascospores and Dothiorella anamorphs. Mycologia 97:513529.

31. Phillips, A. J. L., Crous, P. W., and Alves, A. 2007. Diplodia seriata, the anamorph of Botryosphaeria obtusa. Fungal Div. 25:141-155.

32. Punithalingam, E. 1980. Plant diseases attributed to Botryodiplodia theobromae. In: Biblioteca Mycologica. J. Cramer, Berlin.

33. Punithalingam, E. 1976. Botryodiplodia theobromae. Description of Pathogenic Fungi and Bacteria 519. Commonwealth Mycological In- 
stitute, Kew, Surrey, England.

34. Punitthalingam, E., and Waller, J. M., 1976. Botryosphaeria obtusa. Description of Pathogenic Fungi and Bacteria 394. Commonwealth Mycological Institute, Kew, Surrey, England.

35. Radman, L., and Nadazdin, V. 1981. A contribution to the study of two Sphaeropsis species parasites of the bark of grapevine in Herzegovina, Yugoslavia. Phytopathol. Mediterr. 20:83-84.

36. Rovesti, L., and Montermini, A. 1987. A grapevine decline caused by Spaheropsis malorum widespread in the province of Reggio-Emilia. Inf. Fitopatol. 37:1-59.

37. Savocchia, S., Steel, C. C., Stodart, B. J., and Somers, A. 2007. Pathogenicity of Botryosphaeria species isolated from declining grapevines in sub tropical regions of Eastern Australia. Vitis 46:27-32.

38. Shoemaker, R. A. 1964. Conidial states of some Botryosphaeria species on Vitis and Quercus. Can. J. Bot. 42:1297-1301.

39. SIAP Servicio de Información y Estadística Agroalimentaria y Pesquera, 2006. Ministerio de Agricultura de Mexico, Secretaría de Agricultura, Ganadería, Desarrollo Rural, Pesca y Alimentación (SAGARPA).
40. Slippers, B., Smit, W. A., Crous, P. W., Coutinho, T. A., Wingfield, B. D., and Wingfield, M. J. 2007. Taxonomy, phylogeny and identification of Botryosphaeriaceae associated with pome and stone fruit trees in South Africa and other regions of the world. Plant Pathol. 56:128-139.

41. Smith, M. B., and Hendrix, F. F. 1984. Primary infection of apple buds by Botryosphaeria $o b$ tusa. Plant Dis. 68:707-709.

42. Swofford, D. L. 1999. PAUP*. Phylogenetic Analysis Using Parsimony (*and other methods), version 4.0b4a. Sinauer Associates, Sunderland, MA

43. Taylor, A., Hardy, G. E. St. J., Wood, P., and Burgess, T. 2005. Identification and pathogenicity of Botryosphaeria species associated with grapevine decline in Western Australia. Aust. Plant Pathol. 34:187-195.

44. Téliz, D., and Valle, P. 1979. Eutypa dieback in Mexican vineyards. Plant Dis. Rep. 63:312314.

45. Úrbez-Torres, J. R., Leavitt, G. M., Voegel, T., and Gubler W. D. 2006. Identification and distribution of Botryosphaeria species associated with grapevines cankers in California. Plant Dis. 90:1490-1503.
46. Úrbez-Torres, J. R., Luque, J., and Gubler, W. D. 2007. First report of Botryosphaeria iberica and B. viticola associated with grapevine decline in California. Plant Dis. 91:772.

47. Úrbez-Torres, J. R., Peláez, H., Santiago, Y., Martín, C., Moreno, C., and Gubler, W. D. 2006. Occurrence of Botryosphaeria obtusa B. dothidea and B. parva associated with grapevine trunk diseases in Castilla y León region, Spain. Plant Dis. 90:835.

48. van Niekerk, J. M., Crous, P. W., Groenewald, J. Z., Fourie, P. H., and Halleen, F. 2004. DNA phylogeny, morphology and pathogenicity of Botryosphaeria species on grapevines. Mycologia 96:781-798.

49. White, T. J., Bruns, T., Lee, S., and Taylor, J. 1990. Amplification and direct sequencing of fungal ribosomal RNA genes for phylogenetics. Pages 315-322 in: PCR Protocols, A Guide to Methods and Applications. M. A. Innis, D. H. Gelfand, J. J. Sninsky, and T. J. White, eds. Academic Press, San Diego, CA

50. Wood, P. M., and Wood, C. E. 2005. Cane Dieback of Dawn Seedless table grapevines (Vitis Vinifera) in Western Australia caused by Botryosphaeria rhodina. Aust. Plant Pathol 34:393-395. 